\title{
France prunes research spending but supports big science
}

Paris

AFTER two years of internal turmoil and a budget increase below the rate of inflation, France's largest science research body, the CNRS (Centre National de la Recherche Scientifique), has taken the step of giving priority to big science. As is usual nowadays, however, the money is to be found by pruning new research jobs and by seeking industrial sponsors.

"It's not an easy budget", said Serge Feneuille, director-general of CNRS, as he outlined the priorities for 1988 on 23 November. Spurred on by the government, the CNRS has decided to focus support on its best laboratories, to ensure that France continues to compete internationally. "This will mean some painful decisions have to be made", said Feneuille, "but no discipline will be sacrificed".

The European Synchrotron Radiation Facility (ESRF), at Grenoble, is to receive FF45.5 million ( $£ 4.6$ million) in the coming year, a decision that must be linked to France's unwillingness to participate in Britain's spallation neutron source, ISIS, at the Rutherford Appleton Laboratory (see Nature 329, 381; 1987). The Vivitron at Strasbourg will also receive FF19.4 million in 1988.

A number of new initiatives were announced by Feneuille, including provision of FF6 million for the Very Large Telescope (VLT), planned for a site in Chile. Commitment to VLT from other European partners has not yet been found but, according to Feneuille, "we are going ahead as if it were a certainty". The money will go to interferometry and mirrorpolishing laboratories, where France has a solid reputation. Similarly, high-temperature superconductor research will get an extra FF8 million, and information technology an extra FF5 million.

Two new laboratories will be created in life sciences, one in plant biology, at Gifsur-Yvette, near Paris, and the other in pharmacological biotechnology.

This veneer of progressive dynamism conceals a heavy reliance on contributions from industry, as could be anticipated from research minister Jacques Valade's budget speech in the Senate on 21 November. Valade called the collaboration between industry and public "the priority of priorities" and sees it as a way not only to co-finance, with CNRS, around 50 research laboratories over the next five years, but also to make up for a stagnation in researcher training and recruitment (see Nature 329, 380; 1987).

An extra 40 doctoral training scholarships will be available to engineers in the fields of chemistry and physics, if industrial co-sponsors can be found to match the FF10 million the CNRS has earmarked for this purpose. About 200 of these scholarships are awarded each year. Similarly, 20 two-year postdoctoral fellowships will be available on the same partnership basis with the private sector. The reservation of these opportunities for research areas with an obvious technology bias is related to the government's new scheme of financial incentives (a year's salary) for trained scientists leaving the CNRS for industry.

The defence budget, given a 10 per cent increase for 1988 , will also be tapped. The French military research establishment, DRET, has a $25 \mathrm{~kW}$ high-energy laser which will form the basis of a joint laboratory with researchers from CNRS studying metallurgical applications.

The linear accelerator now at the University of Paris (Orsay) will move to a new, 10,000-square-metre high-energy

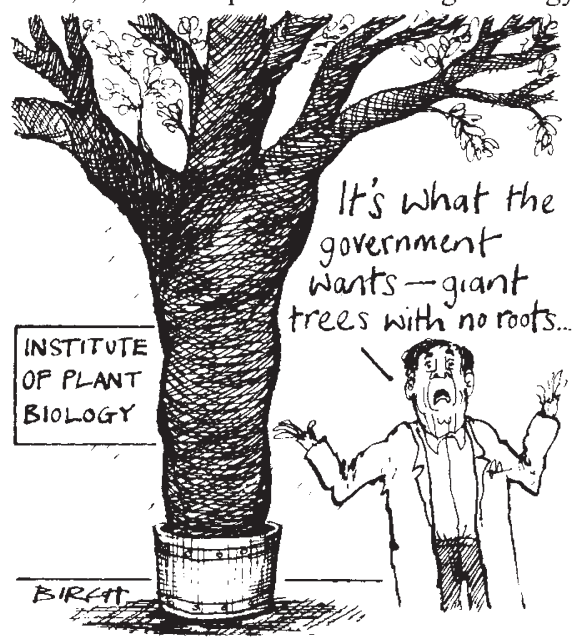

physics laboratory at the Cité Descartes, a science park at Marne-la-Valeé, the new town under construction just outside Paris. "It will be good to have two highenergy physics groups in Paris", said Feneuille, an atomic and molecular physicist, "a bit of competition is constructive".

A comparison of French expansiveness with increasing British reticence towards European big science areas will be inevitable. In his Senate speech, Jacques Valade admitted that "it has become fashionable to caricature France's position", but this could also be said of Britain. In reply to a question about Britain's role in ESRF, Feneuille said "the British scientific community must be present, since they have some of the best researchers in the world, especially in molecular biology and protein crystallography. But it would be difficult to accept that they are present at cut-price, on the same level as a small country".

Peter Coles
Britain drags feet

London

ENVIRONMENT ministers from eight European states have agreed to adopt a series of measures to reduce pollution in the North Sea. Meeting in London last week, ministers from Belgium, Denmark, France, West Germany, the Netherlands, Norway, Sweden and Britain decided to end incineration at sea by 1994 and halve by 1995 the volume of toxic chemicals discharged.

Britain would not agree to cease dumping sewage sludge, but gave a commitment at the meeting that the levels of contaminants would not be further increased. Dumping of industrial wastes that cannot be shown to be harmless will be phased out by the end of 1989. It was agreed to ban the dumping of garbage from ships, to increase aerial surveillance of the sea and to set up a scientific task force to monitor and assess pollution.

S.L.H.

\section{Go-ahead for BRAIN \\ Brussels}

WITH its penchant for memorable acronyms, the European Commission has approved a budget of $£ 690,000$ for six neurocomputer projects under the title of BRAIN (Basic Research in Adaptive Intelligence and Neurocomputers). The projects, regarded as the European Community's response to Japan's Human Frontier Science Program, will involve around $\mathbf{1 0 0}$ researchers in 28 laboratories in West Germany, Britain, France and the Netherlands.

B.C.

\section{Indifference bemoaned London}

More in sorrow than in anger, Sir George Porter, president of the Royal Society of London, this week wrung his hands over the indifference of the British to "the pursuit of knowledge for its own sake". He was delivering this year's anniversary address to the Royal Society.

Porter said that, while there are signs that the United Kingdom is prospering in some respects, it seems that "the pursuit of natural knowledge is to be allowed to diminish". Pleading that the argument about the state of British science should not degenerate into demands that "the government should hand out more money", he said the "deeper and more serious" trouble is that "neither governments nor the country" seem to have much interest in research.

Porter went on to describe how he had been told by ministers and civil servants that there is "too much science", that Britain "can leave it to others" and that the "importance of Nobel prizes went out with Harold Wilson". He said that the "only argument for improving natural knowledge which carries any weight today is that it creates wealth, and even this is refuted in some quarters". 